\author{
KAMILA ZIÓtKOWSKA-WEISS \\ Uniwersytet Pedagogiczny w Krakowie, Polska - Pedagogical University of Cracow, Poland \\ MICHAL ŻEMtA \\ Uniwersytet Pedagogiczny w Krakowie, Polska - Pedagogical University of Cracow, Poland
}

\title{
Charakterystyka turystyki miejskiej wśród studentów krajów Grupy Wyszehradzkiej
}

\section{City Tourism Profile among Students in the Visegrad Countries}

\begin{abstract}
Streszczenie: Obecnie coraz większą rolę w wyjazdach turystycznych odgrywają wyjazdy krótkie, trwające kilka dni. Wpisanie się w ten trend jest jednym z najbardziej oczywistych kierunków współpracy pomiędzy krajami Grupy Wyszehradzkiej (V4), którą tworzą cztery kraje: Polska, Republika Czeska, Słowacja oraz Węgry. Turystyka, a turystyka pomiędzy nimi w szczególności ma szansę stać się widocznym elementem statystyk wyjazdów i przyjazdów zagranicznych w każdym z czterech krajów. Miasta od wieków przyciągały turystów, oferując im zakwaterowanie, wyżywienie, rozrywkę i inne atrakcje. Nie ulega wątpliwości, że turystyka na obszarach miejskich - przyjmująca różne formy, takie jak turystyka krajoznawcza, kulturalna, kulinarna czy imprezowa - stała się w skali globalnej czymś powszechnym. Nie brakuje w Europie miast, które co roku przyciągają rzesze turystów z kraju i z zagranicy, a organizację wielkich imprez, takich jak koncerty, wydarzenia kulturalne, pokazy lotnicze, coraz częściej postrzega się jako skuteczny sposób na znaczne zwiększenie napływu turystów - zarówno w krótszej, jak i dłuższej perspektywie. Celem artykułu jest przedstawienie kierunków wyjazdów wśród studentów z krajów Grupy Wyszehradzkiej w ujęciu turystyki miejskiej. Dla realizacji celu przeprowadzono badania ankietowe wśród 197 studentów turystyki we wszystkich krajach Grupy Wyszehradzkiej. Autorzy podjęli próbę znalezienia wspólnych cech, dzięki którym może rozwijać się turystyka miejska pomiędzy krajami Grupy, oraz analizy aktywności turystycznej studentów w poszczególnych krajach V4. Przedstawione zostały kraje, które - zdaniem respondentów - są najbardziej atrakcyjne w zakresie uprawiania city breaks oraz najbardziej atrakcyjne w zakresie możliwości zwiedzania dziedzictwa kulturowego (pomniki, muzea). W artykule przedstawione zostały także wyniki badania, mówiące o tym, który kraj - zdaniem ankietowanych - jest najbardziej atrakcyjny pod względem możliwości zrobienia zakupów.
\end{abstract}

Abstract: The Visegrad Group (V4) is an institutionalised form of co-operation between four countries:
Poland, The Czech Republic, Slovakia and Hungary. Currently, short tourist trips lasting for several days
play an increasingly important role. Fitting into this trend is one of the most obvious directions of co-op-
eration between the countries of the Group and tourism between them may become a visible element
of statistics of the departures and arrivals abroad in each of the four countries. Cities have been attracting
tourists for centuries, offering them accommodation, food, entertainment and other attractions. There
is no doubt that tourism in urban areas that adopt a variety of forms (including nature tourism, cul-
tural tourism, culinary tourism or party tourism) has become a universal thing on a global scale. There 
is a number of cities in Europe that attract crowds of visitors from the country and abroad and large-scale events, such as concerts, cultural events and air shows are increasingly perceived as an effective way to increase tourists' flows significantly, both in the short and long term. The objective of the article is to present the directions of travelling among students from the Visegrad Group with reference to urban tourism. In order to fulfill the objectives, a survey has been conducted among 197 students of tourism in all countries of the Visegrad Group. The authors have made an attempt at finding the common features through which urban tourism can be developed between the countries of the Group, as well as they conducted an analysis of the tourism activity of the students in the V4 countries. The countries that according to the respondents - are the most attractive in terms of city breaks and the most attractive in terms of visiting cultural heritage (monuments, museums) have been presented. The article will also include the results of the survey stating which country is the most attractive with regard to shopping according to the respondents.

Słowa kluczowe: city break; kraje Grupy Wyszehradzkiej; studenci; turystyka; turystyka miejska

Keywords: city break; city tourism; students; tourism; Visegrad Countries

Otrzymano: 10 listopada 2017

Received: 10 November 2017

Zaakceptowano: 17 maja 2018

Accepted: 17 May 2018

Sugerowana cytacja/Suggested citation:

Ziółkowska-Weiss, K., Żemła, M., (2018). Charakterystyka turystyki miejskiej wśród studentów krajów Grupy Wyszehradzkiej. Przedsiębiorczość - Edukacja [Entrepreneurship - Education], 14, 359-373. DOI: $10.24917 / 20833296.14 .26$

\section{Wstęp}

Dynamiczny rozwój zjawiska turystyki masowej w drugiej połowie ubiegłego wieku, a wraz z nim rozwój badań tego zjawiska, przez wiele lat wiązany był przede wszystkim z obszarami posiadającymi istotne walory przyrodnicze, zwłaszcza umożliwiające uprawianie turystyki wypoczynkowej. Jednak na przełomie wieków, wraz ze zmianami w preferencjach i zachowaniu turystów, dostrzegana jest zmiana w tej zależności, a wśród obszarów recepcyjnych ruchu turystycznego coraz większą rolę zaczynają odgrywać aglomeracje wielkomiejskie. Według Światowej Organizacji Turystyki (UNWTO, 2012) turystyka miejska dotyczy podróży dokonywanych przez podróżnych do miast cechujących się dużą gęstością zaludnienia, przy czym z reguły są to pobyty krótkie, trwające od jednego do trzech dni. Można zauważyć, że jest to stwierdzenie bardzo ogólne, skoncentrowane na stronie popytowej rynku turystyki miejskiej, przez co w pełni nie oddaje złożoności zjawiska (Zmyślony, 2015). Pomimo stale rosnącej liczby publikacji naukowych odnoszących się do tematu turystyki miejskiej (zob. m.in. Law, 2002; Maitland, Ritchie, 2009; Heeley, 2011; Majewska, 2011; Spirou, 2011; UNWTO, 2012; Zmyślony, 2013; Richards, 2014; Zmyślony, 2015), samo zdefiniowanie, czym jest ta forma turystyki, nastręcza dużych trudności. Konieczne jest bowiem rozpatrywanie miasta zarówno jako celu podróży turystycznych, jak i jako motywu podejmowania aktywności turystycznej. Podobnie jak w przypadku innych form turystyki, także w przypadku turystyki miejskiej należy także uwzględnić różnorodność aktywności turystów w miastach oraz kontekst, w jakim są one postrzegane i rejestrowane w umysłach odbiorców, jak również efekty społeczne, 
ekonomiczne, kulturowe i przestrzenne wynikające z ruchu turystycznego (Madurowicz, 2008; Zmyślony, 2015). Zdaniem Gołembskiego (2009: 353), problem dokładnego zdefiniowania turystyki miejskiej ma swoje źródło w kilku przyczynach. Są nimi: różnorodności obszarów miejskich, trudności w określeniu roli turystyki w miastach oraz brak możliwości wyraźnego wyróżnienia, kim jest turysta miejski. Poza tym Gołembski zauważa też dwa przeciwstawne trendy - z jednej strony miasta cechują się dużą różnorodnością ze względu na wielkość, czas założenia, lokalizację i pełnione funkcje, z drugiej strony - w wyniku procesów globalizacyjnych - ich centra coraz bardziej się do siebie upodabniają. Bardziej szczegółowe są rozważania Kowalczyka (2005) oraz Ashwortha i Page’a (2011), którzy dokonują rozróżnienia na turystykę miejską i turystykę w mieście, której zakres znaczeniowy jest szerszy. Podział zaproponowany przez cytowanych autorów znajduje zastosowanie w wielu pracach badaczy - zarówno polskich, jak i zagranicznych (Zmyślony, 2015). Według Ashwortha i Page’a (2011: 7), w turystyce miejskiej „głównym motywem przyjazdu turystów są niektóre aspekty miejskości”. Natomiast Kowalczyk (2005: 57) przez turystykę miejską rozumie „turystykę, której celem jest odwiedzanie i poznawanie miasta traktowanego jako dziedzictwo kulturowe i uznawanego za niepodzielny element przestrzeni turystycznej”. W tym znaczeniu jest ona jedną z form turystyki, a w jej wyróżnieniu istotny jest kontekst, a więc emocjonalne nastawienie turysty do miasta jako odwiedzanego miejsca, a nie tylko typu odwiedzanej przestrzeni (Zmyślony, 2015). W dalszej części wywodu Kowalczyk podkreśla (2005: 158), że turyści uprawiający turystykę miejską traktują miasto w kategoriach symbolicznych, poszukują jego „ukrytych wymiarów”, pozostając „pod wpływem czegoś co można nazwać genius loci”.

Niewątpliwie, współcześnie wielkie miasta stanowią jedne z najważniejszych obszarów recepcyjnych na globalnym rynku turystycznym (Hayllar, Griffin, Edwards, 2008; Niemczyk, 2010; Law, 2002; Maitland, Newman, 2009; Page, Hall, 2003). Czynnikami, które decydują o ich znaczeniu i sile, są m.in. dziedzictwo historyczne i kulturowe, wielofunkcyjność miast wynikająca z ich zróżnicowanej struktury społeczno-gospodarczej, wielki potencjał ludnościowy, a także rozwinięta infrastruktura oraz dostępność komunikacyjna (Niemczyk, 2010). Trzeba jednak pamiętać, że miasta pełnią dwojaką funkcję na globalnym rynku turystycznym. Są nie tylko ważnymi miejscami docelowymi ruchu turystycznego, lecz także obszarami generującymi ogromny wyjazdowy ruch turystyczny, największymi na świecie generatorami międzynarodowego i krajowego ruchu turystycznego (Matczak, 2008), których mieszkańcy cechują się najwyższym poziomem aktywności turystycznej.

\section{Geneza zjawiska city break}

Termin city break można przetłumaczyć na język polski jako imprezę mającą na celu krótkotrwały odpoczynek w mieście. Jak twierdzą Prylińska i Ratkowska (2009), city break niewątpliwie istnieje od pewnego czasu na europejskim rynku turystycznym - określenie to pojawia się w artykułach branżowych, jest obecne w ofertach coraz większej liczby organizatorów turystyki bądź też indywidualnych usługodawców, używane jest przez internautów przy opisie wrażeń z podróży na różnego rodzaju portalach turystycznych itp. City break nazywamy krótkotrwałym (2-6 dni) pobytem w mieście o sporej popularności turystycznej oraz bogatej i atrakcyjnej ofercie kulturalno-turystycznej, a także dobrze skomunikowanym z innymi miastami. W czasie pobytu turysta korzysta $\mathrm{z}$ kilku usług 
turystycznych - w tym noclegu i wyżywienia, często także z usługi przewodnickiej, atrakcji turystycznych i kulturalnych oferowanych przez miasto: stałych (muzea, teatry, parki itp.) oraz o charakterze krótkotrwałym (wystawy) lub nawet jednorazowym (koncerty, inscenizacje, zawody sportowe, festyny itd.). Czasem pobyt obejmuje także wycieczkę poza miasto.

Można założyć, że city break jest prostą odpowiedzią na zmiany w popycie na usługi turystyczne, gdyż zjawisko to niewątpliwie wpisuje się w najnowsze trendy światowej turystyki XXI w. Prognoza Światowej Organizacji Turystycznej (Tourism 2020..., 1997) zakłada m.in., że „wyraźnemu skróceniu ulegnie czas spędzany przez turystę w podróży”, a przecież city breaks w najprostszej postaci to nic innego jak krótkie, przez co dostępne przez cały rok, „wypady” turystyczne do miast.

Według Trewa i Cockrella (2002) city break to krótkotrwałe, rekreacyjne podróże do mniejszych lub większych miast, nieobejmujące noclegu w innym miejscu podczas podróży. Podobnie tę formę turystyki definiują Awedyk, Makarewicz i Weltrowska (2013: 12), zdaniem których city break to „stosunkowo krótkotrwałe, zazwyczaj weekendowe wycieczki poza granice kraju macierzystego do modnych metropolii, ze szczególnym uwzględnieniem miast stołecznych, łączące odpoczynek z turystyką poznawczo-kulturową, najczęściej organizowane samodzielnie przez turystę przy stosunkowo niskim nakładzie finansowym". W ujęciu cytowanych autorów city break jest więc turystyką zagraniczną i indywidualną, co wydaje się definicją zbyt wąską, odnoszącą się do większości podróży tego typu, jednak z pewnością można mówić także o city break w turystyce krajowej, z rzadka pojawiają się także wyspecjalizowani organizatorzy tej formy turystyki (Costa, Perez, Moital, 2005).

W literaturze angielskiej pojawiają się dwa określenia na tego typu wyjazdy: city break weekend i city break holiday różniące się od siebie w zasadzie tylko długością pobytu turystów w danym mieście (www.citybreaksguide.com). Pojęcie city break weekend odnosi się tylko i wyłącznie do propozycji wyjazdów weekendowych (piątek-niedziela), spędzanych najczęściej w dobrze skomunikowanych, przez co łatwo i tanio dostępnych, stolicach europejskich bądź innych miast o atrakcyjnej ofercie turystyczno-kulturowej, natomiast city break holiday to również krótkie (z reguły 2-6-dniowe) wyjazdy do miast, ale odbywające się niekoniecznie podczas weekendu. Mogą to być weekendy przedłużone, krótkie wyjazdy świąteczne, wycieczki pozwalające turystom na udział w wydarzeniach kulturalnych, konferencjach, targach czy zakupach, a nawet wyjazdy sprzedawane przez organizatora wypoczynku jako wycieczki fakultatywne do miast i ich obszarów satelitarnych podczas dłuższego pobytu o charakterze urlopowym.

Jak podkreślają Prylińska i Ratkowska (2009), istotnymi czynnikami wpływającymi na dynamiczny rozwój oferty city break w Europie i w Polsce są także:

- rozwój środków transportu, zwłaszcza tanich linii lotniczych, co pozwala na szybkie dotarcie do wybranych miast i na skrócenie pobytów do weekendu czy kilku dni (przedłużony weekend, pobyty świąteczne);

- rozwój Internetu jako źródła szybkiej, powszechnej informacji turystycznej, płaszczyzny komunikowania się pomiędzy wszystkimi sektorami rynku turystycznego, platformy, dzięki której można dokonać rezerwacji czy zapłacić za daną usługę, dzięki rozwojowi kart płatniczych i związanymi z tym usługami (Internet banking) (Marcinkowska 2006; Nalazek 2001);

- ogólna zmiana trybu życia - bardziej intensywna i absorbująca praca, przy której nie 
wystarcza jeden urlop rocznie, a zarazem coraz wyższe dochody, które dają możliwość częstszego, choćby krótkoterminowego wyjazdu;

- minimalizacja czasu poświęcanego na odpoczynek dzienny poprzez zapełnianie czasu wolnego kolejnymi aktywnościami, do których jesteśmy częściowo zobligowani przez społeczeństwo konsumpcyjne nastawione na czerpanie korzyści ze wszystkiego; które wymusza na jednostce partycypację w określonych imprezach, formach rozrywki, a także nabywanie i użytkowanie określonych kategorii dóbr, które dalej stają się podstawą samookreślenia (Krajewski, 1997);

- co z tego wynika, permanentnie kurczący się czas wolny przestaje być czasem wolnym kreowanym przez jednostkę, a staje się czasem wolnym zaprojektowanym przez specjalistów dla konkretnej grupy społecznej, do przynależności w której przyznaje się lub dopiero pretenduje jednostka - bez względu na to, czy mówimy o tzw. kulturze wysokiej czy popularnej (Szablikowska-Manyś, Miedzińska, 2007);

- wzrost popularności wyjazdów jawiących się jako oryginalne, szukanie przez turystów nowości rynkowych (bardzo często w ofercie city break pojawiają się określenia typu „oryginalny”, „,inspirujący”, „niecodzienny”, „nieoczekiwany” itp.);

- silna indywidualizacja współczesnego społeczeństwa i coraz większa niechęć do wielkich imprez zorganizowanych; city break daje możliwość zorganizowania wyjazdu jedynie dla siebie lub swojej grupy znajomych bez potrzeby podporządkowywania się terminom i programom narzuconym przez biuro podróży.

Często na stronach internetowych polskich biur turystycznych nazwą city break określa się krótkotrwałe, najczęściej weekendowe wyjazdy do stolic europejskich oraz innych dużych miast o ciekawej i bogatej ofercie kulturalnej, co pozostaje w zgodzie z pierwotną interpretacją pojęcia. Na pierwszy plan wysuwają się atrakcyjne i łatwo dostępne miasta, budzące konkretne skojarzenia i będące same w sobie marką turystyczną, jak stolice: Paryż, Londyn, Madryt, Rzym, Lizbona czy inne, duże i dobrze skomunikowane miasta europejskie, np. cieszące się największą popularnością: Barcelona, Mediolan, Florencja czy Sankt Petersburg. Można przyjąć, że city break traktowany jest tu bardziej jako swoisty produkt turystyki na obszarach miejskich niż forma turystyki miejskiej czy kulturowej. W propozycjach biur pojawiają się bowiem różnego rodzaju aktywności: od zwiedzania miasta, poprzez uczestnictwo w wydarzeniach i imprezach kulturalnych czy sportowych, po zakupy czy clubbing.

\section{Turystyka miejska związana ze zwiedzaniem dziedzictwa kulturowego}

Dla ponad połowy turystów biorących udział w światowym ruchu turystycznym jedną z głównych motywacji jest zazwyczaj zainteresowanie środowiskiem, kulturą i dziedzictwem (Kaufman, 1999). Turystyka kulturowa oraz turystyka dziedzictwa kulturowego jest najszybciej rozwijającym się segmentem przemysłu turystycznego, ponieważ istnieje tendencja do większej specjalizacji wśród turystów (Kerstetter, Confer, Graefe, 2001). Trend ten jest widoczny we wzroście liczby turystów poszukujących przygody, kontaktu z kulturą, historią czy interakcji z miejscową ludnością (Hollinshead, 1993). Jak zauważyli Ziółkowska-Weiss i Popiel (2014), ze względu na skłonności ludzi do poszukiwania nowości, w tym również poznawania tradycyjnych kultur, dziedzictwa narodowego, turystyka kulturowa stała się nowym obszarem popytu turystycznego, który wart jest uwagi i rozwijania i który przyczynia się do rozwoju turystyki miejskiej. Turystyka dziedzictwa, 
w ramach szerszej kategorii „turystyki kulturowej”, jest obecnie mocnym filarem strategii turystycznej w wielu krajach (Richards, 1995). Głównym elementem zainteresowania turystów jest dziedzictwo kulturowe, rozumiane jako kompleks zabytków, budynków i stanowisk archeologicznych o wyjątkowej, uniwersalnej wartości z punktu widzenia historii, sztuki czy nauki. Howard (2003: 6) określa dziedzictwo jako: „coś, co ktoś chciałby zachować lub zebrać i przekazać przyszłym pokoleniom”. Ze względu na jego rolę jako nośnika wartości historycznych z przeszłości, dziedzictwo jest postrzegane jako część tradycji kulturowej społeczeństwa (Nuryanti, 1996). Zatem za Silberberg (1995), wszelkie wizyty osób spoza społeczności przyjmującej, których motywacją do podróży, w całości lub w części są zainteresowania historyczne, artystyczne, naukowe lub chęć poznawania stylu życia czy dziedzictwa danej wspólnoty, regionu lub instytucji, nazywane są turystyką kulturową. Zeppel i Hall (1990) ponadto dodają, iż turystyka ta opiera się również na zaangażowaniu oraz stymulacji przez sztukę, krajobraz, zabytki, budynki, pomniki, a także na empirycznym poszukiwaniu spotkania z naturą lub doznania historii danego miejsca. Dziedzictwo obejmuje więc elementy trwałe, jak również niematerialne w postaci praktyk kulturowych, tradycji czy wiedzy (McKercher, 2002). Zatem podróże kulturowe czy te związane z dziedzictwem oparte są na nostalgii za przeszłością i chęcią doświadczenia różnorodnych krajobrazów kulturowych. W świetle powyższego dodanie do słowa „kultura” czy „dziedzictwo” pojęcia „turystyka” jest tak naprawdę formą nowoczesnej świadomości (Nuryanti, 1996) i próbą usystematyzowania takiej aktywności turystów.

Jak piszą Ziółkowska-Weiss i Popiel (2014), dziedzictwo, tożsamość regionu są atrakcyjne dla turystów i stanowić mogą produkt turystyczny, który umożliwi odwiedzającym rzeczywiste doświadczenie historii, tradycji oraz docenienie danego miejsca. Dziedzictwo kulturowe stanowi ogromny i zróżnicowany zbiór ludzkiej historii na całym świecie. Wzrost wiedzy na temat świata, rozwój środków transportu, jak również dostępności do podróży przyczyniają się do ogromnego popytu na elementy turystyki dziedzictwa. Człowiek z natury jest ciekawy nowych kultur, osobistego doświadczania innych społeczności. $\mathrm{W}$ rezultacie i w odpowiedzi na ten trend rynku turystycznego oraz duży popyt wiele regionów na świecie wprowadza pewne formy działalności turystycznej, by przyciągnąć odwiedzających i zaprezentować swoją kulturę i zabytki.

\section{Turystyka handlowa jako zjawisko turystyki miejskiej}

We współczesnych czasach bardzo rozwiniętej turystyki ludzie podróżują z różnych powodów. Wśród nich szczególne, a ostatnio znaczące, miejsce zajmują zakupy. Nie ulega wątpliwości, że przyczyniły się do tego różne okoliczności, m.in. dynamiczny rozwój galerii handlowych, obserwowany nie tylko w Polsce, lecz także w całej Europie. Należy podkreślić, że rozkwit tego rodzaju placówek oraz ułatwienia w migracjach turystycznych zyskały na znaczeniu m.in. dzięki procesom integracyjnym. Swoboda przemieszczania się między krajami, coraz lepsza sytuacja ekonomiczna podróżujących, niejednokrotnie chęć naśladowania stylów życia innych konsumentów poskutkowały wzmożoną aktywnością turystyczną, motywowaną także chęcią robienia zakupów. Pod pojęciem „turystyka handlowa” Instytut Turystyki rozumie wszelkie podróże, których celem są zakupy na potrzeby własne. B. Hołderna-Mielcarek i K. Majchrzak (2007) piszą, że z zakupów tych wyłączone są zakupy związane z zaspokojeniem popytu turystycznego. Przechodząc do motywów uczestnictwa w turystyce zakupowej czy handlowej, należy zwrócić uwagę na klasyfikację 
Taubera (1972), który rozróżnia w tym względzie motywy osobiste (np. oderwanie się od codzienności) i społeczne (np. nawiązywanie znajomości z ludźmi o podobnych zainteresowaniach, przyjemność w prowadzeniu negocjacji cenowych). Inną klasyfikację motywów uczestnictwa w turystyce zakupowej zaproponował Timothy (2005). Wyodrębnił on motywy dotyczące: produktów (mogą to być np. produkty unikalne, wolnocłowe, tzw. duty-free), obszaru recepcji (miejsc charakterystycznych dla danych produktów, sklepów, butików itp.) oraz cen (np. tanie destynacje, destynacje, gdzie ceny są relatywnie niższe niż w miejscu zamieszkania turysty, destynacje bogate w miejsca do „polowania” na okazje cenowe). Zdaniem Niemczyk (2015) mnogość przywołanych motywów podróżowania w celach zakupowych pozwala stwierdzić, że turystyka handlowa stanowi ważną część turystyki wpływającej na migracje między miastami w poszczególnych krajach.

Głównie centra handlowe i ich oferta są tym, co czyni zadość chęci podróżowania w celach zakupowych. Centra handlowe stają się atutem każdej metropolii, aglomeracji. Współczesne galerie, w których realizuje się turystyka zakupowa, to obiekty składające się z różnego rodzaju elementów tworzących multifunkcjonalne centra handlu i kultury (centra handlowo-usługowo-rozrywkowe). Poza wieloma sklepami placówki te oferują różnego typu punkty gastronomiczne, punkty usługowe, jak. np. zakłady fryzjerskie, obiekty rozrywkowe, np. kina, wydarzenia kulturalne i sportowe organizowane na terenie centrum handlowego. „Z czasem centra te są przekształcane poprzez dodawanie nowych elementów tak, że w chwili obecnej funkcjonują na rynku tzw. centra piątej generacji. Centra te odzwierciedlają strukturę małego miasta, z punktami handlowo-usługowymi, biurami i hotelami” (Śmigielska 2011: 42). Zadaniem tego typu obiektów jest przyciągnięcie nie tylko mieszkańców, lecz także turystów - dlatego też ich lokalizacja koncentruje się blisko dworców kolejowych, autobusowych, metra, obwodnic miast. Jak podkreśla Grzesiuk (2013), dynamiczny rozwój placówek handlowych i ich różnorodność przyczyniły się do wykreowania nowej, nietypowej oferty „Zwiedzania sklepów” - są już firmy oferujące wycieczki po sklepach. Rola zakupów jako motyw migracji turystycznych zyskuje na znaczeniu. Tego rodzaju podróżowanie po Europie osiąga coraz większe rozmiary. Serwis FRU.PL w styczniu 2013 r. przeprowadził badania sondażowe, z których wynika, że coraz częściej samodzielnie organizujemy podróże do europejskich stolic wyprzedażowych, wyjazd na zakupy za granicę nie jest już ekstrawagancją. Wśród miast najchętniej odwiedzanych przez Polaków w celach zakupowych znalazły się: Londyn (22\%), Paryż (16\%), Mediolan (11\%), Barcelona (9\%) i Madryt (7\%) (Niemczyk, 2015).

\section{Atrakcyjność turystyki miejskiej wśród studentów krajów Grupy Wyszehradzkiej}

Badania ankietowe przy pomocy kwestionariusza umieszczonego w Internecie przeprowadzone zostały w pierwszej połowie 2016 r. Wzięło w nich udział 197 studentów kierunków związanych z turystyką ze wszystkich czterech krajów. W sposób zamierzony badania skoncentrowano na obszarach położonych w relatywnej bliskości granic państw V4, a więc w Polsce w Katowicach i Krakowie, w Republice Czeskiej w Brnie, na Słowacji w Bańskiej Bystrzycy i Bratysławie, na Węgrzech w Sopron i Gyor. Zwłaszcza w tak dużym kraju jak Polska wyniki uzyskane na tak wybranym obszarze nie mogą być reprezentatywne dla całego kraju, a znajomość i częstotliwość wyjazdów mieszkańców Warszawy, Poznania czy Gdańska do krajów Grupy będzie z pewnością mniejsza. To samo jednak można powiedzieć także o mieszkańcach czeskiej Pragi lub Pilzna czy węgierskiego Szegedu. 
Badania odbywały się w ramach współpracy między wykładowcami różnych uczelni, którzy udostępniali studentom link do kwestionariusza, który następnie upowszechniany był także metodą tzw. śnieżnej kuli, dlatego badacze mieli bardzo ograniczony wpływ na końcową strukturę badanej próby. Ostatecznie w badaniach wzięło udział 78 studentów ze Słowacji, 43 z Polski, 46 z Republiki Czeskiej i 28 z Węgier. W badaniach proszono studentów o wskazanie swoich dotychczasowych doświadczeń turystycznych oraz o subiektywną ocenę poszczególnych krajów. Jako potencjalne punkty odniesienia i porównania w badaniach pytano także o kolejnych pięć krajów Europy Środkowej: Niemcy, Austrię, Litwę, Rumunię i Słowenię.

W badaniu zapytano respondentów o dziewięć krajów Europy Środkowej: Litwę, Polskę, Republikę Czeską, Słowację, Węgry, Austrię, Słowenię, Rumunię oraz Niemcy. Wszyscy respondenci byli proszeni o wskazanie co najwyżej pięciu krajów spośród wymienionej dziewiątki, które - ich zdaniem - są najbardziej atrakcyjne w zakresie uprawiania city breaks (tab. 1), oraz pięciu najbardziej atrakcyjnych krajów w zakresie możliwości zwiedzania dziedzictwa kulturowego (pomniki, muzea) w danym kraju (tab. 2). Respondenci zapytani również zostali o pięć - ich zdaniem - najbardziej atrakcyjnych krajów z możliwością zrobienia zakupów (turystyka handlowa) (tab. 3).

Rycina 1 przedstawia procentową ilość wskazań krajów uznanych za najbardziej atrakcyjne pod względem uprawiania city breaks łącznie wśród wszystkich respondentów z czterech krajów wchodzących w skład Grupy Wyszehradzkiej.

Odpowiadając na pytanie dotyczące krajów najbardziej atrakcyjnych pod względem uprawiania city breaks, wszyscy respondenci z czterech krajów wchodzących w skład Grupy Wyszehradzkiej wskazali Austrię oraz Republikę Czeską. Na wysokim, trzecim, miejscu ankietowani umieścili Niemcy. Zdaniem badanych, krajem, który jest najmniej atrakcyjny pod względem możliwości uprawiania city breaks, jest Rumunia oraz Litwa.

Tabela 1 pokazuje wyniki, które państwa wśród respondentów poszczególnych krajów są najbardziej atrakcyjne pod względem możliwości uprawiania city breaks.

Ryc. 1. Kraje najbardziej atrakcyjne pod względem uprawiania city breaks

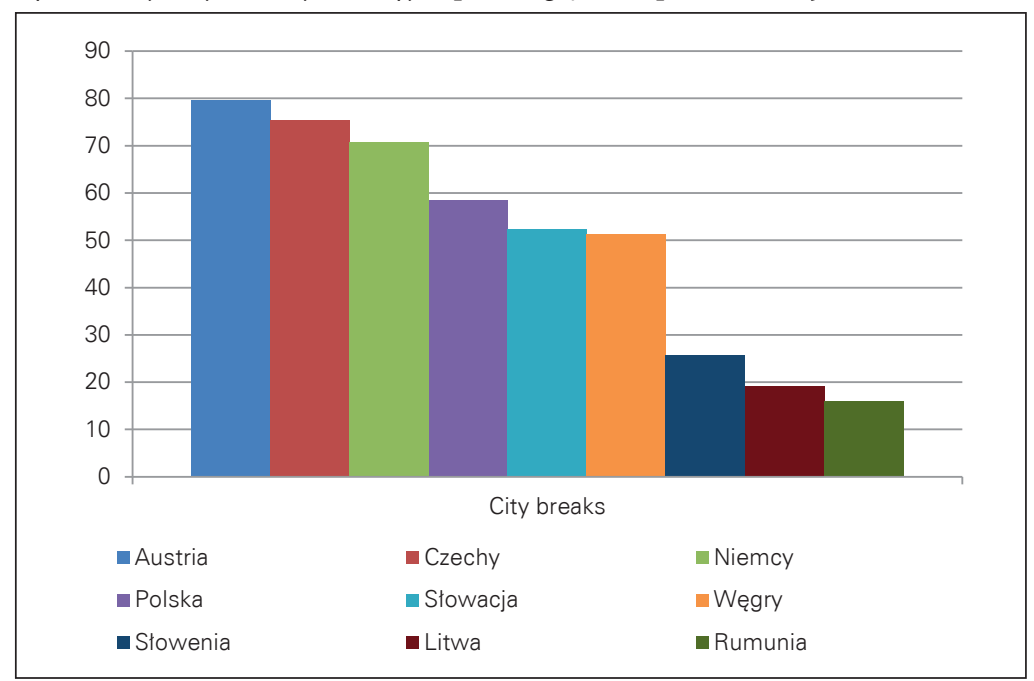

Źródło: opracowanie własne autorów na podstawie badań ankietowych 
Tab. 1. Kraje najbardziej atrakcyjne pod względem uprawiania city breaks - zdaniem respondentów

\begin{tabular}{|c|c|c|c|c|c|c|c|c|c|}
\hline Kraj & 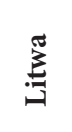 & $\begin{array}{l}\frac{\pi}{5} \\
\frac{\pi}{0} \\
0\end{array}$ & $\begin{array}{l}\hat{\bar{u}} \\
\text { J }\end{array}$ & $\begin{array}{l}\frac{\pi}{5} \\
\frac{\pi}{3} \\
\frac{0}{\omega}\end{array}$ & ${ }_{3}^{\infty}$ & & $\begin{array}{l}\frac{\pi}{3} \\
\frac{3}{0} \\
\frac{\tilde{c}}{\omega}\end{array}$ & 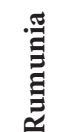 & 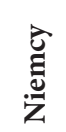 \\
\hline Ogółem \% & 19,0 & 58,5 & 75,4 & 52,3 & 51,3 & 79,5 & 25,6 & 15,9 & 70,8 \\
\hline Czesi & 21,7 & 45,7 & 82,6 & 65,2 & 41,3 & 87,0 & 34,8 & 10,9 & 65,2 \\
\hline Węgrzy & 17,9 & 57,1 & 67,9 & 25,0 & 53,6 & 71,4 & 14,3 & 25,0 & 82,1 \\
\hline Polacy & 11,6 & 79,1 & 69,8 & 39,5 & 53,5 & 72,1 & 27,9 & 23,3 & 69,8 \\
\hline Słowacy & 21,8 & 55,1 & 76,9 & 61,5 & 55,1 & 82,1 & 23,1 & 11,5 & 70,5 \\
\hline
\end{tabular}

Źródło: opracowanie własne autorów na podstawie badań ankietowych

Dokonując dokładnej analizy odpowiedzi respondentów z poszczególnych krajów, wyraźnie widać, że Czesi oraz Słowacy największą liczbę głosów oddali na Austrię, wskazując ten kraj jako najbardziej atrakcyjny do uprawiania city breaks. Innego zdania są Węgrzy, według których tym krajem są Niemcy. Najgorzej oceniona została Słowenia przez Słowaków oraz Litwa przez Polaków. Na uwagę zasługuję odpowiedź polskich respondentów, którzy jako jedyni spośród wszystkich przedstawicieli z czterech krajów wskazali swój kraj jako najbardziej atrakcyjny i przychylny do uprawiania city breaks. Pomimo bliskości, zarówno Węgrzy, jak i Polacy nisko ocenili swoich sąsiadów Słowaków. Wysoką liczbę wskazań zanotowała natomiast Republika Czeska wśród Słowaków.

W dalszej części badania respondenci proszeni byli o wybór spośród powyższych krajów pięciu najbardziej atrakcyjnych pod względem możliwości zwiedzania dziedzictwa kulturowego (pomniki, muzea). Rycina 2 przedstawia procentową ilość wskazań krajów najbardziej atrakcyjnych w zakresie możliwości zwiedzania dziedzictwa kulturowego (pomniki, muzea), łącznie wśród wszystkich respondentów z czterech krajów wchodzących w skład Grupy Wyszehradzkiej.

W pytaniu tym wyraźnie widać, że zdaniem ankietowanych, podobnie jak w poprzednim pytaniu, najbardziej atrakcyjnymi krajami pod tym względem jest Republika Czeska oraz Austria. Również Polska znalazła się na wysokim, trzecim miejscu. Najgorzej ocenione zostały Litwa oraz Słowenia.

Analiza odpowiedzi na to pytanie wskazuje, że bardzo wysoko oceniona została Republika Czeska przez Polaków i Słowaków oraz Austria przez Czechów. Porównując to pytanie z poprzednim, zdecydowanie mniejszą popularność wśród ankietowanych zyskały Niemcy, aczkolwiek zarówno Czesi, jak i Polacy wskazali ten kraj jako trzeci najbardziej atrakcyjny w zakresie możliwości zwiedzania w nim dziedzictwa kulturowego. Najniżej, podobnie jak w pytaniu poprzednim, ocenione zostały Słowenia oraz Litwa, przy czym należy zaznaczyć, że zdecydowanie najniższe noty kraje te uzyskały od respondentów z Węgier. Tak samo jak w pytaniu dotyczącym oceny kraju pod względem możliwości uprawiania city break, Polacy jako najbardziej atrakcyjny kraj pod względem możliwości uprawiania turystyki związanej z dziedzictwem kulturowym wskazali Polskę. W kolejnym pytaniu poproszono respondentów o wskazanie najatrakcyjniejszych państw w zakresie turystyki handlowej, zakupowej. 
Tab. 2. Kraje najbardziej atrakcyjne w zakresie możliwości zwiedzania dziedzictwa kulturowego (pomniki, muzea)

\begin{tabular}{|c|c|c|c|c|c|c|c|c|c|}
\hline Kraj & 胥 & $\begin{array}{l}\frac{\pi}{3} \\
\frac{0}{0} \\
2\end{array}$ & $\begin{array}{l}\hat{\bar{v}} \\
\text { Uु }\end{array}$ & $\begin{array}{l}\frac{\pi}{\frac{\pi}{7}} \\
\frac{3}{5} \\
\frac{0}{5}\end{array}$ & $\begin{array}{l}b_{0}^{2} \\
3\end{array}$ & 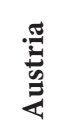 & $\begin{array}{l}\frac{\pi}{3} \\
\frac{0}{0} \\
\text { है }\end{array}$ & 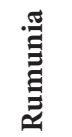 & 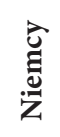 \\
\hline Ogółem \% & 20,0 & 70,8 & 82,1 & 52,3 & 56,4 & 71,8 & 12,3 & 25,6 & 63,1 \\
\hline Czesi & 17,4 & 63,0 & 87,0 & 47,8 & 43,5 & 87,0 & 15,2 & 23,9 & 78,3 \\
\hline Węgrzy & 17,9 & 57,1 & 75,0 & 25 & 85,7 & 42,9 & 7,1 & 35,7 & 50,0 \\
\hline Polacy & 20,9 & 95,3 & 86,0 & 27,9 & 65,1 & 69,8 & 16,3 & 23,3 & 74,4 \\
\hline Słowacy & 21,8 & 66,7 & 79,5 & 78,2 & 48,7 & 74,4 & 10,3 & 24,4 & 52,6 \\
\hline
\end{tabular}

Źródło: opracowanie własne autorów na podstawie badań ankietowych

Tab. 3 . Kraje najbardziej atrakcyjne w zakresie możliwości uprawiania turystyki handlowej

\begin{tabular}{|c|c|c|c|c|c|c|c|c|c|}
\hline Kraj & 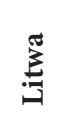 & $\begin{array}{l}\frac{\pi}{5} \\
\frac{5}{0} \\
0\end{array}$ & $\begin{array}{l}\hat{\mathbb{E}} \\
\text { J }\end{array}$ & $\begin{array}{l}\frac{\pi}{\pi} \\
\frac{\pi}{3} \\
\frac{0}{\omega}\end{array}$ & $\frac{3}{3}$ & 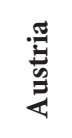 & $\begin{array}{l}\frac{\pi}{3} \\
\frac{\tilde{\sigma}}{\tilde{*}} \\
\frac{\overrightarrow{0}}{\omega}\end{array}$ & 畄 & 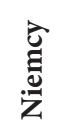 \\
\hline Ogółem \% & 11,3 & 67,2 & 70,3 & 43,6 & 48,7 & 87,7 & 13,3 & 11,3 & 75,9 \\
\hline Czesi & 23,9 & 63,0 & 71,7 & 50,0 & 23,9 & 89,1 & 13,0 & 15,2 & 87,0 \\
\hline Węgrzy & 3,6 & 42,9 & 46,4 & 57,1 & 50,0 & 89,3 & 21,4 & 14,3 & 75,0 \\
\hline Polacy & 14,0 & 62,8 & 69,8 & 32,6 & 48,8 & 81,4 & 11,6 & 9,3 & 83,7 \\
\hline Słowacy & 5,1 & 80,8 & 78,2 & 41,0 & 62,8 & 89,7 & 11,5 & 9,0 & 65,4 \\
\hline
\end{tabular}

Źródło: opracowanie własne autorów na podstawie badań ankietowych

Rycina 3 przedstawia procentową ilość wskazań krajów najbardziej atrakcyjnych w zakresie możliwości uprawiania turystyki handlowej łącznie wśród wszystkich respondentów z czterech krajów wchodzących w skład Grupy Wyszehradzkiej.

Zdaniem respondentów krajem, który jest zdecydowanie najbardziej atrakcyjny pod względem możliwości uprawiania turystyki handlowej, jest Austria. Na kolejnym miejscu znalazły się Niemcy oraz Republika Czeska. Najmniej atrakcyjnymi krajami okazały się Litwa oraz Rumunia.

Dokonując oceny tego pytania, zarówno dla Czechów, Węgrów, jak i Słowaków, Austria znalazła się na pierwszym miejscu wśród wszystkich tych krajów jako najbardziej atrakcyjna pod względem możliwości uprawiania turystyki zakupowej. Jedynie Polacy wskazali, że Niemcy - ich zdaniem - są najlepszym miejscem do uprawiania tego typu turystyki. Na taki charakter odpowiedzi może mieć fakt bliskości geograficznej. Jednak dokładnie analizując odpowiedzi Czechów, w ich opinii ani Słowacja, ani Polska, jako najbliższy sąsiad kraju, nie są najlepszymi państwami do uprawiania turystyki handlowej, za to ich zdaniem zarówno Niemcy, jak i Austria do takich należą. Najsłabiej przez Węgrów i Słowaków oceniona została Litwa, Polacy najgorzej ocenili Rumunię, natomiast Czesi -Słowenię. Polska najlepiej oceniona została przez Słowaków, a najsłabiej przez Węgrów. 
Ryc. 2. Kraje najbardziej atrakcyjne w zakresie możliwości zwiedzania dziedzictwa kulturowego (pomniki, muzea)

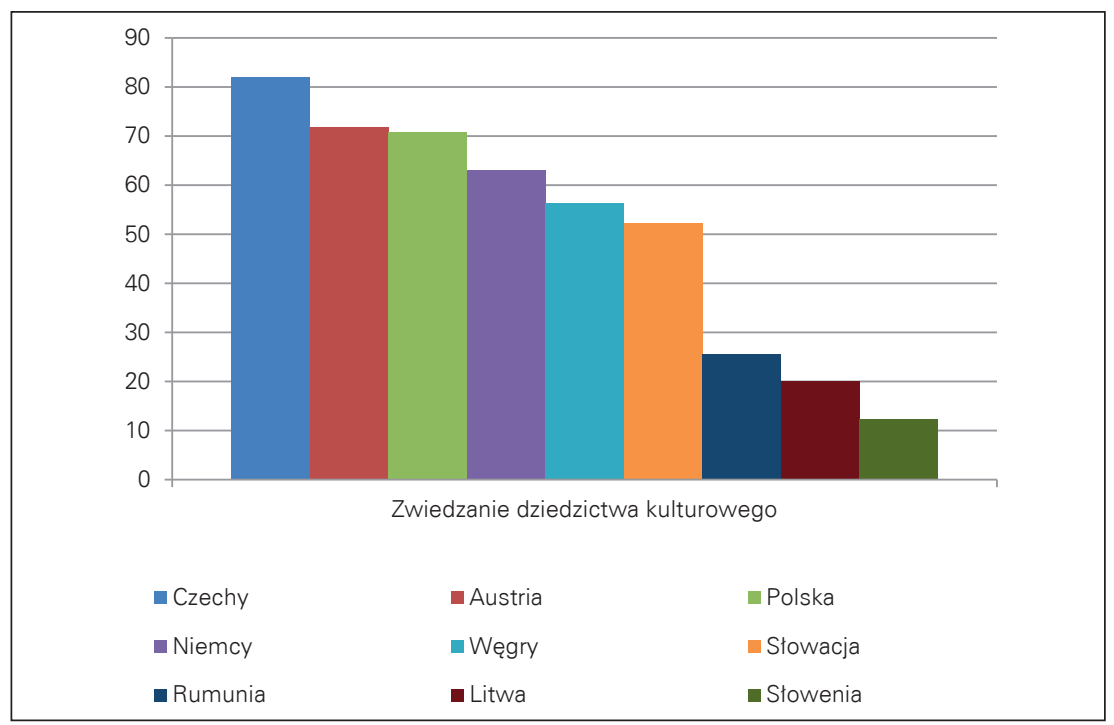

Źródło: opracowanie własne autorów na podstawie badań ankietowych

Ryc. 3. Kraje najbardziej atrakcyjne w zakresie możliwości uprawiania turystyki handlowej

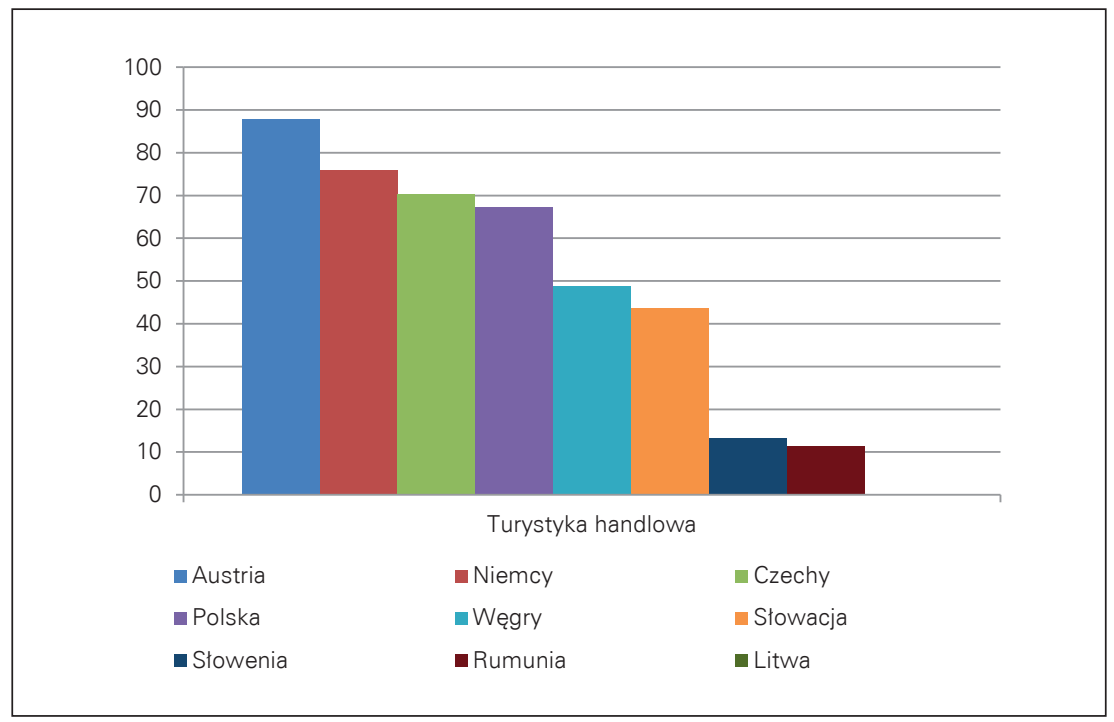

Źródło: opracowanie własne autorów na podstawie badań ankietowych

\section{Zakończenie}

Rosnąca popularność turystyki city break oraz turystyki miejskiej wpłynęła na pojawienie się nowego spojrzenia na atrakcyjność turystyczną regionów. Turystyka miejska to współcześnie coraz częściej turystyka lotnicza, a podczas krótkich wyjazdów aktywność turysty 
koncentruje się na relatywnie małym obszarze. Zatem próba zarysowania mapy atrakcyjności turystycznej określonego terytorium prowadzi raczej do wskazania konkretnych punktów koncentracji tej atrakcyjności, a nie tradycyjnych regionów turystycznych. Także w przypadku państw grupy V4 o ich atrakcyjności dla turystyki miejskiej stanowią przede wszystkim najbardziej atrakcyjne metropolie. Republika Czeska z Pragą, Polska z Warszawą i Krakowem oraz Węgry z Budapesztem oceniane były znacznie wyżej niż Słowacja, której stolica Bratysława nie jest postrzegana jako typowe miejsce dla turystyki kulturowej czy city break. Wyjątkiem jest jedynie zaskakująco wysoka ocena Słowacji w atrakcyjności dla city break, będąca nawet nieznacznie wyższa niż ocena Węgier. Warto zwrócić uwagę, że w znacznym stopniu ten wynik Słowacja zawdzięcza bardzo wysokiej ocenie wśród Słowaków, podczas gdy Węgrzy nie docenili swojego kraju aż tak bardzo.

Generalnie, mimo że współczesna turystyka miejska to często podróże dość dalekie, lotnicze, w wynikach badań można zaobserwować także nurt przeciwny, pokazujący przywiązania turystów do podróżowania po własnym kraju. Nawet w kategorii city break kraje, z których pochodzili respondenci, otrzymywały zawyżone wyniki od swoich mieszkańców. Może to być częściowo związane z preferencją dla turystyki krajowej w ogóle (Szromek, Żemła, 2014), a częściowo także wynikać z docenienia walorów swojego kraju.

Ciekawych wniosków dostarcza także analiza odpowiedzi na pytanie związane z turystyką zakupową. Ewidentne jest, że respondenci nie wskazywali na kraje tradycyjnie postrzegane jako tanie (Rumunia, Litwa), ale wręcz przeciwnie, najwyższe oceny otrzymały kraje tzw. Starej Unii Europejskiej uchodzące za droższe niż kraje, które do Unii wstąpiły w XXI w. Zatem warunkiem atrakcyjności dla turystyki handlowej był jednak wizerunek modnych i ekskluzywnych sklepów wielkich miast Austrii i Niemiec, a nie możliwość zrobienia tanich zakupów.

Literatura

References

Ashworth, G., Page S. (2011). Urban tourism research: Recent progress and current paradoxes. Tourism Management, 32(1), 1-15.

Awedyk, M., Makarewicz, M., Weltrowska, J. (2013). Indywidualne city break jako reprezentacyjny trend turystyki europejskiej w XXI wieku. Prace Naukowe Uniwersytetu Ekonomicznego we Wrocławiu, 304, 11-18.

Costa, C., Peres, R., Moital, M. (2005). Lisbon as a city break destination: a competitive analysis as perceived by London travel agents. Journal of Tourism and Development, 2, 67-80.

Gołembski, G. (red.) (2009). Kompendium wiedzy o turystyce. Warszawa: Wydawnictwo Naukowe PWN.

Grzesiuk, A.(2013). Nowoczesne kanały dystrybucji jako kreator form spędzania czasu wolnego. Handel Wewnętrzny, 4(3).

Hayllar, B., Griffin, T., Edwards, D. (2008). Urban tourism precincts: Engaging with the field. W: B. Hayllar, T. Griffin, D. Edwards (red.), City Spaces - Tourist Places: Urban Tourism Precincts. Elsevier, Oxford, 3-18.

Heeley, J. (2015). Urban destination marketing in contemporary Europe - what does "good" look like?. International Journal of Tourism Cities, 1(1), 36-49.

Hollinshead, K. (1993). Encounters in Tourism. VNR's Encyclopedia of Hospitality and Tourism, 636-651.

Hołderna-Mielcarek, B., Majchrzak, K. (2007). Strategia rozwoju turystyki zakupowej na przykładzie miasta Poznania. W: J. Mikołajczyk (red.), Zarzadzanie usługami w gospodarce rynkowej: handel, gastronomia, turystyka. Poznań: WSHiU. 
Howard, P. (2003). Heritage: Management, Interpretation, Identity. Bloomsbury Academic.

Kaufman, T.J., (1999). A study of the motivations behind heritage site selection in the United States. Virginia Polytechnic Institute and State University.

Kerstetter, D.L., Confer, J.J., Graefe, A.R. (2001). An exploration of the specialization concept within the context of heritage tourism. Journal of Travel Research, 39, 267-274.

Kowalczyk, A. (2005). Nowe formy turystyki miejskiej. Prace I Studia Geograficzne, 35, 155-197.

Krajewski, M. (1997). Konsumpcja i współczesność. O pewnej perspektywie rozumienia świata społecznego. Kultura i Społeczeństwo, 3, Warszawa.

Law, C.M. (2002). Urban Tourism: The Visitor Economy and the Growth of Large Cities (second edition), Continuum, London.

Maitland, R., Newman, P. (2009). Developing world tourism cities. W: R. Maitland, P. Newman (red.), World Tourism Cities: Developing Tourism Off the Beaten Track, Oxon: Routledge, 1-21.

Maitland, R., Ritchie, B.W. (red.), (2009). City tourism: National Capital Perspective, WallingfordCambridge: CABI.

Majewska, J. (2011). Pomiar i ocena stadium turystycznego miast w ostatnim dziesięcioleciu - Poznań na tle największych miast w Polsce. W: G. Gołembski (red.), Sposoby mierzenia i uwarunkowania rozwoju funkcji turystycznej miasta - przykład Poznania, Poznań: Wyd. Uniwersytetu Ekonomicznego w Poznaniu, 36-65.

Madurowicz, M. (2008b). Rozumienie turystyki miejskiej. W: I. Jażdżewska (red.), Funkcja turystyczna miast, XXI Konwersatorium Wiedzy o Mieście, Łódź: Wydawnictwo Uniwersytetu Łódzkiego, $11-16$.

Marcinkowska, K. (2006). Cały świat w systemie. Wiadomości Turystyczne, 10.

Matczak, A. (2008). Turystyka miejska - kierunki badań geograficznych. W: A. Matczak (red.), Turystyka miejska, Bydgoszcz: Wydawnictwo Uczelniane Wyższej Szkoły Gospodarki w Bydgoszczy, 17-23.

McKercher, B. (2002). Towards a classification of cultural tourist., International Journal of Tourism Research, 4, 29-38.

Nalazek, M. (2001). Nowoczesne technologie w turystyce i hotelarstwie. Rynek Turystyczny, 13/14.

Niemczyk, A. (2010). Turystyka miejska w Polsce w warunkach globalizacji rynku turystycznego. W: J. Sala (red.), Konkurencyjność miast i regionów na globalnym rynku turystycznym, Warszawa: PWE, 478-489.

Niemczyk, A. (2015). Turystyka zakupowa - istota i uwarunkowania jej rozwoju. Handel Wewnętrzny, $3(356), 174-184$.

Nuryanti, W. (1996). Heritage and Postmodern tourism. Annals of Tourism Research, 23(2), 249-260.

Page, S. J., Hall, C. M. (2003). Managing urban tourism. Harlow: Prentice Hall.

Prylińska, M., Ratkowska, P. (2009). City break - próba wyjaśnienia i zdefiniowania zjawiska w odniesieniu do polskiego rynku usług turystycznych. Turystyka Kulturowa, 10.

Richards, G. (1995). Production and Consumption of European Cultural Tourism. Annals of Tourism Research, 22(2), 261-283.

Richards, G. (2014). Creativity and tourism in the city. Current Issues in Tourism, 17(2), 119-144.

Silberberg, T. (1995). Cultural tourism and business opportunities for museums and heritage sites. Tourism Management, 16(5), 361-365.

Spirou, C. (2011). Urban tourism and urban change. Cities in a global economy. New York: Routledge.

Szablikowska-Manyś, M., Miedzińska, I. (2007). Stereotyp w pojmowaniu i kreowaniu czasu wolnego kobiet na wybranych przykładach. W: M. Kazimierczaka (red.), Turystyka i podróżowanie w aksjologicznej perspektywie, Poznań: Wydawnictwo AWF.

Szromek, A.R., Żemła, M. (2014). Preference for domestic offer in tourism among students in Central European Countries. European Journal of Tourism, Hospitality and Recreation, 5(2), 183-196.

Śmigielska, G. (2011). Handel w gospodarce opartej na wiedzy. W: M. Woźniak, (red.), Nierówności społeczne a wzrost gospodarczy, Rzeszów: Uniwersytet Rzeszowski. 
Tauber, E.M. (1972). Marketing notes and communications: Why do people shop?. Journal of Marketing, 36.

Timothy, D.J. (2005). Shopping tourism, retailing, and leisure. Aspects of Tourism, 23.

Tourism 2020 vision. Influences, directional flows and key trends. A new forecast from the World Tourism Organization. Executive summary, (1997), Madrid: World Tourism Organization.

Trew, J., Cockerell, N. (2002). The European market for UK city breaks. Insights, 14(58), 85-111.

UNWTO, (2012). Global Report on City Tourism - Cities 2012 Project, World Tourism Organization, Madrid.

Zeppel, H., Hall, C. (1992). Arts and heritage tourism. W: B. Weiler, C. Hall (red.), Special Interest Tourism, Londyn: Belhaven, 47-68.

Ziółkowska-Weiss, K., Popiel M. (2014). Rozwój turystyki dziedzictwa na wybranych przykładach w Polsce. Annales Universitatis Paedagogicae Cracoviensis, Studia Geographica VII, 131-143.

Zmyślony, P. (2013). Internacjonalizacja zarządzania funkcją turystyczną w dużym mieście. Prace Geograficzne Instytutu Geografii i Gospodarki Przestrzennej UJ, 134, 51-68.

Zmyślony, P. (2015). Funkcja turystyczna w procesie internacjonalizacji miast. Poznań-Kraków: Proksenia.

Kamila Ziółkowska-Weiss, dr, absolwentka kulturoznawstwa z historią sztuki na Uniwersytecie Jagiellońskim oraz geografii na Uniwersytecie Pedagogicznym w Krakowie. Ukończyła podyplomowe studia na Uniwersytecie Ekonomicznym w Krakowie na kierunku zarządzanie turystyką międzynarodową. Adiunkt w Zakładzie Turystyki i Badań Regionalnych Uniwersytetu Pedagogicznego w Krakowie. Czynny pilot wycieczek. Autorka kilkunastu publikacji naukowych. Główne zainteresowania naukowe to turystyka kulturowa, mniejszości narodowe i grupy etniczne w Małopolsce oraz Polonia w USA.

Kamila Ziółkowska-Weiss, $\mathrm{PhD}$, Graduate of Culture studies at the Jagiellonian University and of Geography at the Pedagogical University of Cracow. She has graduated from postgraduate studies in international tourism management at the Cracow University of Economics. Since 2012 she has been a research worker, acting as an assistant in the department of Tourism and Regional Studies at the Pedagogical University of Cracow. An active tourist guide. The author of numerous academic publications. Her main academic interests are in cultural tourism, ethnic groups in Małopolska and Polish minority in the USA.

\section{Adres/Address:}

Uniwersytet Pedagogiczny im. Komisji Edukacji Narodowej w Krakowie

Instytut Geografii

Zakład Turystyki i Badań Regionalnych

ul. Podchorążych 2

30-084 Kraków, Polska

e-mail: kamilacamela@wp.pl

Michał Żemła, dr hab., prof. Uniwersytetu Pedagogicznego w Krakowie, w Instytucie Geografii, Zakładzie Turystyki i Badań Regionalnych. Ukończył studia magisterskie na Wydziale Organizacji i Zarządzania Politechniki Śląskiej w Gliwicach, otrzymał doktorat na Akademii Ekonomicznej w Katowicach, a habilitację na Uniwersytecie Ekonomicznym we Wrocławiu. Jego zainteresowania badawcze są związane z marketingiem obszarów turystycznych ze specjalnym uwzględnieniem obszarów górskich. Jest autorem lub współautorem trzech książek i prawie 100 artykułów naukowych.

Michał Żemła, PhD, associate professor, Pedagogical University of Cracow, Institute of Geography, Department of Tourism and Regional Studies. He has graduated from the Faculty of Organization and Management of the Silesian University of Technology in Gliwice, he obtained his $\mathrm{PhD}$ at the Economic University in Katowice and habilitation at the Economic University in Wroclaw. 
His research interests are connected with tourism destinations marketing, with special emphasis on mountain areas. He is the author or a co-author of three books and almost 100 articles.

\section{Adres/Address:}

Uniwersytet Pedagogiczny im. Komisji Edukacji Narodowej w Krakowie Instytut Geografii

Zakład Turystyki i Badań Regionalnych

ul. Podchorążych 2

30-084 Kraków, Polska

e-mail: Michal.Zemla@up.krakow.pl 